\title{
Friedrich List (1789-1846) e o Sistema Nacional de Economia Política
}

\author{
Rosalina Lima IZEPÃO ${ }^{1}$ \\ Elohá Cabreira BRITO \\ Leonel Rodrigues BORGES ${ }^{3}$
}

\section{RESUMO}

A Alemanha só conseguiu se tornar Estado Nacional em 1871, durante o período de luta por esta unificação que surgiu a Escola Histórica Alemã de economia. Os economistas alemães, pertencentes a tal escola, entendiam que o modelo clássico não servia para a realidade alemã e George Friedrich List, por meio da sua obra "O Sistema Nacional de Economia Política", deu importantes contribuições para essa escola. Assim, o objetivo deste estudo é analisar o pensamento econômico desenvolvido na Confederação Germânica no século XIX, conhecido como Escola Histórica Alemã, até a formação do Estado Nacional Alemão, em 1871, visando verificar as contribuições de List. Metodologicamente, trata-se de uma pesquisa histórico-bibliográfica-descritiva. Para atendimento do objetivo proposto, o trabalho encontra-se estruturado em cinco seções, incluindo a introdução e considerações finais. A segunda seção aborda um breve histórico do processo de unificação da Alemanha. A terceira apresenta o contexto histórico do surgimento da Escola Histórica Alemã de Economia, destacando seus pressupostos teóricos mais importantes, e crítica à economia política clássica. A quarta expõe as principais ideias de List, que defendia que o desenvolvimento alemão ocorreria somente através do protecionismo, nacionalismo e um Estado forte e centralizador. A considerações finais ressaltam que no início do século XX a Alemanha se tornou uma das nações mais industrializadas do mundo seguindo estes pressupostos, mostrando que o pensamento de List apontava um caminho efetivo para o desenvolvimento. Hoje, mais de um século depois, seus pensamentos continuam atuais em razão da existência de significativas diferenças entre o nível de desenvolvimento das nações.

Palavras-chave: unificação alemã, List, sistema nacional.

\section{Friedrich List (1789-1846) and the National System of Political Economy}

\begin{abstract}
Germany only became National State in 1871, during the period of struggle for this unification that emerged the German Historical School of economics. The German economists, belonging to such a School, understood that the classical model was not germane to the German reality and George Friedrich List, through his work "The National System of Political Economy", made important contributions to this school. Thus, the objective of this study is to analyse the economic thinking developed in the German Confederation in the nineteenth century, known as the German Historical School, until the formation of the German National State in 1871, in order to verify the contributions of List. Methodologically, this is a historical-bibliographic-descriptive research. To fulfill the proposed objective, the work is structured in five sections, including the introduction and final considerations. The second section addresses a brief history of Germany's unification process. The third presents the historical context of the emergence of the German Historical School of economics, highlighting its most important theoretical assumptions, and criticism of classical political economy. The fourth outlines List's main ideas, which argued that German development would come only through protectionism, nationalism, and a strong and centralizing state. The final considerations point out that at the beginning of the twentieth century Germany became one of the most industrialized nations in the world following these assumptions, showing that List's thought pointed to an effective path for development. Today, more than a century later, his thoughts remain current because of the existence of significant differences between the level of development of the nations.
\end{abstract}

Key Words: German unification, List, national system.

\footnotetext{
${ }^{1}$ Historiadora. Mestrado em Economia e Doutorado em História Econômica pela USP. Professora Associada do Departamento de Economia da UEM. E-mail rlizepao@uem.br

${ }^{2}$ Bacharel em Ciências Econômicas. Mestrado em Economia Aplicada pela Universidade Estadual de Maringá. Doutoranda do PPGE da Universidade Federal do Rio Grande do Sul. E-mail: eloha.cabreira@gmail.com

${ }^{3}$ Bacharel em Ciências Econômicas. E-mail: leonelborges91@gmail.com
} 


\section{INTRODUÇÃO}

Até o início do século XIX a Alemanha estava fragmentada em centenas de territórios, que, no seu conjunto eram chamados de Império Sacro Germânico. Em 1818, estes territórios foram agrupados em 39 estados independentes denominados Confederação Germânica. O Estado Nacional Alemão só surgiu em 1871, isto é, no final do século XIX, após muita luta pela sua unificação. Durante o período que se estendeu dos anos 1840 até 1870, também se desenvolveu, na referida Confederação, além dos movimentos pela sua emancipação, uma teoria econômica, que se contrapunha à teoria econômica clássica, ficando conhecida como Escola Histórica Alemã.

Nesta época, ou seja, século XIX, outros países europeus que já haviam consolidado o seu Estado Nacional no século XVI, avançavam no seu processo de industrialização. A Inglaterra, por exemplo, havia passado pela I Revolução Industrial, em 1750, e caminhava para a II Revolução Industrial, ocorrida em 1850/60. Assim, o capitalismo desenvolvido na Alemanha foi do tipo tardio, também conhecido como prussiano, uma vez que este país só conseguiu se industrializar no final do século XIX.

Diante do exposto, pretende-se, com o presente estudo, analisar o pensamento econômico desenvolvido na Confederação Germânica no século XIX, conhecido como Escola Histórica Alemã, até a formação do Estado Nacional Alemão, em 1871. Analisando as contribuições de George Friedrich List (1789-1846), por meio da sua obra "O Sistema Nacional de Economia Política", publicada em 1841, para o surgimento do referido pensamento.

O interesse por List e sua obra se deve a diversos fatores, entre os quais se destacam: a forte influência da Escola Histórica Alemã, na "Alemanha" do século XIX e a manutenção dos pilares do pensamento econômico listiano; o fato do seu pensamento econômico ter se constituído a base teórica que fundamentou a teoria cepalina, na América Latina, por meio da Comissão Econômica da América Latina e do Caribe (Cepal), criada em 1948, pela Organização das Nações Unidas (ONU); a grande influência no pensamento econômico brasileiro representada por Celso Furtado, além da adoção do modelo de desenvolvimento por Substituição de Importações (ISI).

Metodologicamente, a pesquisa desenvolvida pode ser caracterizada, por seus objetivos, como histórico-bibliográfica-descritiva, com base em dados qualitativos obtidos em livros e artigos científicos, além da obra original de List intitulada Sistema Nacional de Economia Política, publicada em 1841. Neste livro, Friedrich List expôs suas ideias a respeito de como deveria ser o desenvolvimento econômico alemão e as suas propostas de políticas econômicas governamentais.

Para o atendimento do objetivo geral proposto, o estudo encontra-se estruturado em cinco seções, incluindo esta introdução e as considerações finais. A segunda seção aborda os aspectos históricos sobre a formação do Estado Nacional destacando que o capitalismo desenvolvido na região é o do tipo prussiano, caracterizado pela industrialização tardia, ocorrida no século XIX. A terceira seção capítulo apresentam-se os aspectos históricos relativos ao surgimento da Escola Histórica Alemã de 
Economia, destacando alguns dos principais pontos divergentes da referida escola, em relação à Escola Clássica de Economia que representava o modelo e a visão hegemônica da época, além das fases que caracterizam a EHA, e os seus pressupostos teóricos mais importantes ${ }^{4}$. Na quarta seção apresentam-se as principais ideias preconizadas por List, para o desenvolvimento dos estados que viriam a compor a Confederação que formou o Império Germânico. As considerações finais enfatizam que, embora List tenha falecido em 1846 e a Alemanha só tenha conseguido se tornar um país em 1871, os estudos teóricos de List contribuíram para o surgimento da Escola Histórica Alemã - nas suas duas primeiras fases, de 1840 a 1870, já que a terceira, a Novíssima Escola Histórica Alemã seguiu outros caminhos - e para que no início do século XX a Alemanha tenha se tornado uma das nações mais industrializadas do mundo, mostrando que o pensamento de List apontava um caminho efetivo para o desenvolvimento. Hoje, mais de um século depois, seus pensamentos continuam atuais em razão da existência de significativas diferenças entre o nível de desenvolvimento das nações.

\section{ASPECTOS HISTÓRICOS SOBRE A FORMAÇÃO DO ESTADO NACIONAL ALEMÃO NO SÉCULO XIX}

Na presente seção apresenta-se um breve histórico do processo de unificação da Alemanha, que, diferente dos Estados Nacionais consolidados no século XVI, a exemplo da Inglaterra, Portugal e Espanha $^{5}$, só conseguiu se transformar em Estado Nacional Moderno ${ }^{6}$, em 1871, portanto, no final do século XIX. O objetivo é mostrar que o capitalismo desenvolvido na região que atualmente se chama Alemanha, a partir da sua unificação, é o do tipo prussiano, caracterizado pela industrialização tardia, ocorrida no século XIX. É neste contexto histórico que surgiu e se desenvolveu a Escola Histórica Alemã

\footnotetext{
${ }^{4}$ Entende-se que esta contextualização é importante porque o modelo de desenvolvimento para a Confederação Germânica, atualmente, Alemanha, proposto pela Escola Histórica Alemã se contrapõe totalmente ao modelo defendido pela escola de pensamento clássico. Enquanto a escola clássica defendia o liberalismo econômico, a ordem natural, e os seus pressupostos como universais, na Alemanha, a EHA defendia o intervencionismo estatal, o nacionalismo e a unificação alemã. Ressalta-se, ainda, que a ênfase dada a este período histórico, no presente artigo, deve-se ao fato da obra de List ter sido publicada em 1841, portanto, quando o espaço alemão era constituído pela Confederação Germânica ou Alemã. Sabe-se, no entanto, que o referido espaço foi organizado de diferentes formas ao longo do tempo. Na Antiguidade, por exemplo, referia-se à região de onde partiram os povos que invadiram o Império Romano do Ocidente a partir do século V. Que com a coroação de Carlos Magno Imperador, no século VIII, pelo Papa Leão III, tornou-se Sacro Império Romano Germânico (SIRG), chamado a partir do século XVI de "Império Romano da Nação Germânica" que, ao ser invadido pelas tropas napoleônicas, em 1806, foi substituído pelo que se chamou "Confederação do Reno" ou "Liga Renana". Mais tarde, em 1815, passou a denominar-se Confederação Germânica, em 1866, Confederação da Alemanha do Norte e, em 1871, Império Alemão. A última forma de organização do território se deu em 1990, com a reunificação da Alemanha Ocidental e Oriental. Maiores detalhes podem ser obtidos em Sheehan (1989) e Vieira (2006).

${ }^{5} \mathrm{Na}$ Inglaterra, Portugal e Espanha a centralização do poder político se deu concomitantemente à própria formação da nação. Tratou-se de um processo que se consolidou no século XVI, mas, suas origens de formação datam dos séculos XIII, XI e XIV respectivamente. Por outro lado, na Itália e na Alemanha a centralização foi realizada em âmbito local e não nacional. Nestes últimos, os povos de mesma língua e costumes não formaram um único país, mas, sim, vários, com governos diferentes.

${ }^{6}$ Embora não exista consenso na historiografia ou nas Ciências Sociais sobre o conceito de Estado Nacional, conforme destaca Vieira (2006), utilizam-se, no presente artigo, os termos Estado Nacional Moderno para referirse a um período em que já se tem a formação da nação e a centralização do poder político consolidados.
} 
de economia, também conhecida com EHA, da qual para alguns estudiosos George Friedrich List (17891846) não fez parte, enquanto, para outros, é precursor dos mais importantes.

\subsection{A LUTA PELA FORMAÇÃO DO ESTADO NACIONAL ALEMÃO}

A história da criação do estado nacional alemão, em 1871, difere dos demais países de formação capitalista clássica, tais como: Inglaterra, Portugal, Espanha, Holanda e outros. Enquanto nestes países, no século XVI já se encontravam consolidados os estados absolutistas monárquicos, na Alemanha, assim como na Itália, o que se tinha nesta época eram Principados, Ducados, Condados e até Repúblicas, mas independentes entre si e com normas e legislações próprias. No caso da Alemanha, a região era denominada de Confederação Germânica, composta por 39 "estados", sendo a Prússia e a Áustria as regiões mais desenvolvidas economicamente (ARRUDA, 1980). O mapa 1 mostra como se organizava o território da Confederação Germânica (1815 a 1871).

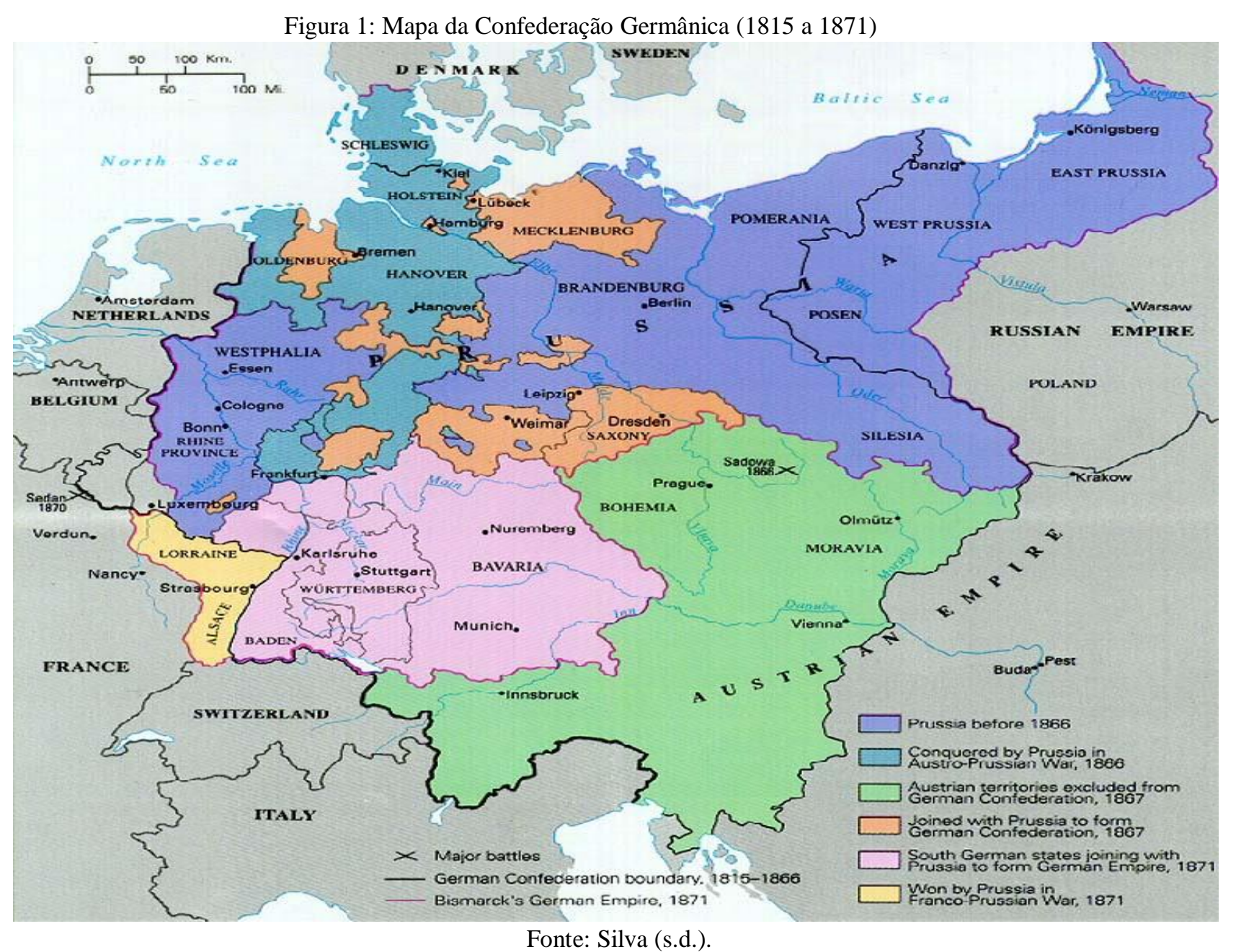

A necessidade de haver a unificação alemã já era grande já no século XVIII, porém com a reordenação da Europa imposta por Napoleão Bonaparte e sua política imperialista desde que 
assumiu o trono francês, em 1799, o alcance deste objetivo ficou mais distante porque as fronteiras que fragmentavam o chamado Império Romano da Nação Germânica, criado no século VIII, ficaram ainda mais fortalecidas com o avanço napoleônico. Em 1806, foi criado por Napoleão Bonaparte a Confederação do Reno ou Liga Renana a partir de uma aliança com vários estados germânicos que serviram como aliados militares dos franceses tendo o Estado Francês como "Protetor". Esta aliança só seria enfraquecida a partir de 1813 e terminaria em 1815 com a derrota de Napoleão na Europa. O povo germânico estava carente de um governo único e, também, de uma política comum. Em 1815, após muitos esforços foi criada a Confederação Germânica, mas os conflitos de origem geográfica, política e econômica, entre os dois Estados mais poderosos da região, ou seja, a Áustria e a Prússia permaneceram fortes (TREUE, 1969; VIEIRA, 2006).

Em se tratando das duas regiões, a Áustria, assim como a grande maioria dos Estados alemães, era um território que dependia da agricultura e não possuía o necessário para o surgimento de indústrias. Já a Prússia era o único Estado com uma indústria nascente e promissora. Essa indústria nascente possibilitou o desenvolvimento comercial e industrial prussiano o que permitiu, a uma parte da população, a possibilidade de não dependeram mais do Estado, em razão do aumento do bem-estar. Foi após as intensas reformas, ocorridas depois de 1806, que se iniciou o surgimento classe trabalhadora industrial (TREUE, 1969).

Até 1806, portanto, início do século XIX, eram as antigas estruturas feudais que predominavam como forma de produção na maior parte do espaço geográfico que constituía a Confederação do Reno e que, em 1871, viria a formar o chamado Império Alemão. Nas relações de trabalho, os camponeses eram obrigados a prestar serviços para os grandes proprietários de terras, numa relação de deveres e obrigações que, apesar de seus defeitos, interessava ao Estado, pois, era vantajoso possuir muitos camponeses eficientes por razões militares e fiscais (ARRUDA, 1980).

Quando Napoleão assumiu o trono francês e impôs pesadas cargas econômicas aos povos germânicos, os mesmos tiveram que potencializar ainda mais a produção agrícola, por meio da sua modernização. Segundo Treue (1969, p. 3) "uma agricultura moderna precisava de trabalhadores que fossem contratados quando fossem necessários, fossem submetidos a uma disciplina laboral e que produzissem o máximo". Eram as formas de produção no estilo feudal dando lugar a um rápido e intenso rompimento social no campo. O grande número de filhos de camponeses, antes obrigado a servir o proprietário da terra devido a obrigação familiar, passou a ser proletariado sem terras. Essas mudanças, no começo do século XIX, explicam de onde 
surgiram os milhões de trabalhadores industriais existentes em meados do século - êxodo rural - e, também, os problemas sociais da segunda metade do século XIX na região que viria se tornar o Estado Alemão ou Alemanha (HUBERMAN, 2011).

A transformação de economia agrária para industrial foi inevitável. A grande líder dessa mudança foi a Prússia devido ao seu precoce começo e da magnitude de suas reformas, que acarretaram na formação de considerável vantagem diante dos outros Estados alemães. O próximo passo prussiano para a hegemonia econômica foi a criação, em 1834, junto com diversos outros Estados, de uma União Aduaneira Alemã, também conhecida como Zollverein (BEAUD, 1996). Conforme destaca Freitas (2015, p. 283), “[...] o processo de unificação dos reinos da Europa Central, dos quais a Prússia e a Áustria eram os mais importantes, iniciou-se com a construção de um espaço econômico, criando uma união aduaneira conhecida como Zollverein, em 1834 [...]”.

O Zollverein ${ }^{7}$ proporcionou os alicerces do crescimento da produção industrial, em razão da ampliação do mercado consumidor, do aperfeiçoamento do ensino técnico e do aumento de produtividade das máquinas. Em 1840, se iniciou a criação das grandes indústrias, sendo de fundamental importância, para esse desenvolvimento, o rápido surgimento das linhas férreas a partir de 1835 que exerceriam uma tripla influência sobre a revolução industrial alemã. Essas influências foram: (i) o surpreendente consumo de ferro e aço, que possibilitaram o auge dos segmentos industriais siderúrgicos e metalúrgicos; (ii) as ferrovias permitiram a ampliação do mercado, em virtude da capacidade de abastecimento de regiões distantes; e, também, (iii) possibilitaram a migração de milhões de trabalhadores rurais que haviam perdido seu emprego em razão das reformas agrícolas implantadas (TREUE, 1969).

Os setores industriais como o têxtil e de construção de maquinaria que surgiram nesta época, alcançaram grande importância. Empresas atingiram níveis altíssimos de atração de trabalhadores e, com esse rápido desenvolvimento, também surgiram os problemas sociais. A jornada de trabalho, em condições precárias, chegava a 16 horas diárias, as condições de trabalho insalubre das fábricas, afetavam inclusive a mão de obra feminina e infantil (BEAUD, 1996).

O desenvolvimento do Zollverein entre os anos de 1834 e 1866 se deu devido ao aumento do número de Estados-Membros, ou seja, a União manteve sua característica

\footnotetext{
${ }^{7}$ Zollverein: liga aduaneira dos Estados germânicos, adotada em 1834. De 1860 a 1870, os reflexos desta política fizeram surgir vários distritos industriais, numerosos centros urbanos, estradas de ferro e minas de carvão (ARRUDA, 1980).
} 
alfandegária. Com isso o espaço delimitado pelo acordo passou a ter características de um espaço econômico. Após a Guerra Austro-Prussiana, em 1866, foi extinta a Confederação Germânica, sendo criada a Confederação da Alemanha do Norte, tendo a Prússia sido mantida como líder político, militar e tributário na região. Contudo, a mais impactante das guerras foi, sem dúvida, a franco-prussiana (1870 a 1871) porque resultou na derrota francesa e marcou o início da hegemonia alemã na Europa continental quando a França teve que aceitar o Tratado de Frankfurt assinado em 10 de maio de 1871, por meio do qual a região de Alsácia-Lorena foi anexado pela Prússia (ARRUDA, 1980 e SAES; SAES, 2013).

Como se pode observar, os primeiros anos do século XIX ficaram marcados pelo declínio do Estado absoluto em todo o território alemão. A “Alemanha” foi tomada por uma onda de indignação contra os velhos poderes. A Prússia, que se sentia ameaçada por outros países, implementou as reformas mais profundas baseadas em políticas tradicionais e no liberalismo moderno. As transformações na administração, economia e exército foram amplamente apoiadas pela população, o que facilitou sua implementação. A população, após a derrota contra a França, esperava o surgimento de uma Alemanha unida, mas não foi o que ocorreu. Surgiram 31 Estados soberanos e a censura voltou a fazer parte do cotidiano. A falta de cumprimento das promessas prussianas, depois de terem atingido o objetivo de independência, provocou um sentimento geral de amargura e irritação.

A Áustria, Estado com uma grande diversidade de nacionalidades, começava a adotar um equilíbrio de políticas internas baseadas em uma administração extremamente eficiente e, por sua grande influência dentro da Confederação Germânica, passou a influenciar a política interior dos Estados-Membros. Diferente do desejo da população de outros Estados soberanos a Áustria combatia energicamente a ideia de um Estado Nacional já que uma desagregação de seu Estado multinacional significaria a criação de vários Estados independentes. Tendências nacionalistas começaram a aflorar nos territórios eslavos, italiano e húngaro criando uma grande onda de mal-estar no território. A passividade do governo fomentou ainda mais os movimentos nacionalistas dentro da monarquia austríaca, o que incentivou a população a desejar a união com o resto da "Alemanha" (ARRUDA, 1980).

$\mathrm{O}$ ano de 1848 iniciou com desordens nos territórios italianos pertencentes à coroa austríaca. A derrubada da monarquia francesa, em fevereiro, foi o estopim para a revolução geral liderada pelos liberais que desejavam a unidade nacional. Os demais Estados, pressionados pelos movimentos revolucionários, aceitaram a criação de um pré-parlamento, cujos membros apresentavam tendências progressistas. Apesar de toda a esperança o que 
ocorreu foi uma grande decepção. A tentativa acabou fracassando por divergência das duas maiores potências alemãs, Áustria e Prússia. Apesar do fracasso a monarquia da Áustria foi tomada por tendências revolucionárias.

Em 28 de março de 1849 a Assembleia Nacional em uma votação, com 290 votos contra 248, aprovou a criação da "pequena Alemanha", que consistia na criação de um império sem a Áustria onde a coroa imperial foi oferecida ao rei da Prússia, Frederico Guilherme IV (Friedrich Wilhelm IV), este recusou a coroa, não em razão da pequena maioria com que se aprovou a medida no parlamento, nem em virtude da oposição dos grandes Estados alemães, entre eles a Áustria, mas por causa do repúdio incondicional deste à revolução (TREUE, 1969).

O problema é que Frederico Guilherme IV recusou o cargo e a revolução fracassou naquele momento. Outra disputa entre Prússia e Áustria ocorreu no âmbito econômico. No início do Zollverein a Áustria não tinha interesse em participar da união alfandegária, pois resistia a acordos que alterassem sua autonomia fiscal e tributária. Com o passar dos anos essa resistência diminuiu e os austríacos passaram a demonstrar interesse em fazer parte do bloco comercial e tarifário unificado. Já a Prússia demonstrava desinteresse, na entrada da Áustria, através de certas ações dirigidas a evitá-la (TREUE, 1969).

\subsection{A UNIFICAÇÃO ALEMÃ E O SURGIMENTO DO ESTADO NACIONAL ALEMÃO}

A entrada da Áustria seria debatida, em 1849, pelos membros da Confederação Germânica, que ainda existia apesar da tentativa prussiana em dissolver a mesma para estabelecer um Estado unificado. Em 1850, os austríacos propuseram a substituição do Zollverein por uma União Econômica onde todos os Estados da Confederação fizessem parte. De acordo com Vieira (2006, p. 108):

A proposta, como foi notada pelos observadores contemporâneos, representou uma demonstração nítida de que a Áustria, doravante, adotaria uma postura mais ativa nos assuntos da Confederação e do Zollverein, o que, por sua vez, poderia ameaçar a posição prussiana. Para viabilizá-la, a fronteira alfandegária entre a Áustria e a Hungria foi abolida em 1850 e o sistema tarifário do Império foi reformado em 1852. O momento mostrava-se oportuno pois o acordo do Zollverein venceria em fins de 1853 e precisaria ser renovado.

Os anos de 1851 e 1852 testemunharam a uma intensa disputa entra Áustria e Prússia no âmbito alfandegário e comercial. A Prússia se recusava a discutir a proposta austríaca, o que fez com que o Congresso Geral do Zollverein ficasse parado, por meses. No fim foi assinado, em 1853, um tratado comercial entre os dois países. O tratado durou doze anos.

Um segundo acordo importante, baseado no acordo comercial entre França e Inglaterra, ocorreu na década de 1860. O fato de a França utilizar o tratado apenas para comércio com a Inglaterra poderia 
atrapalhar os outros países do continente, por isso, se aproveitando desta situação, a França pressionou por diminuições das tarifas aplicadas pelo Zollverein a seu comércio. Mesmo com os Estados do Sul sendo contra essa diminuição tarifária a Prússia negociou unilateralmente com a França objetivando, posteriormente, forçar esse acordo para os outros membros do Zollverein. Já que a União alfandegária deveria ser renovada, em 1865, a entrada dos outros membros nesse acordo com a França poderia ser utilizada, pela Prússia, como condição de sua manutenção. Caso a jogada prussiana fosse bem-sucedida, as chances da Áustria entrar no Zollverein diminuiriam consideravelmente (BEAUD, 2004).

Um acontecimento importante, ocorrido no ano de 1866, foi a "guerra" entre Áustria e Prússia. Os membros do Zollverein que não estivessem dispostos a aceitar o acordo comercial estabelecido com a França poderiam sair da União. A União alfandegária foi renovada por mais 15 anos e sem a saída de nenhum dos membros, indicando uma importante vitória para a Prússia. A Guerra Austro-Prussiana decretou o destino da Confederação Germânica.

Após a Guerra, a Prússia comunicou o fim da Confederação, anexou diretamente Hanover, Hesse-Cassel, Nassau, Schleswig-Holstein e Frankfurt e formou, junto com outros 22 Estados, a Confederação da Alemanha do Norte. O que é ainda mais importante, os Estados do Sul, os mais combativos opositores da Prússia (além da Áustria) na antiga Confederação, estabeleceram com a mesma uma aliança militar, temendo o expansionismo de Napoleão III. A Confederação da Alemanha do Norte era uma união alfandegária e seus tratados específicos foram assinados em meado de 1867. O Zollverein contaria agora com oficiais próprios e com um Conselho e um Parlamento Alfandegários, que apenas a Prússia tinha formalmente o direito de convocar e dissolver. Finalmente, com a Guerra Franco-Prussiana, a Prússia consegue finalmente "quebrar" a resistência dos Estados do Sul e, após a rápida derrota da França, o Segundo Império Alemão foi proclamado em janeiro de 1871, no Salão dos Espelhos, em Versailles (VIEIRA 2006, p. 110).

É evidente que o desenvolvimento econômico e social dos Estados germânicos foi fundamental para a sua unificação e criação do Estado Nacional Alemão, isto é, o país Alemanha, em 1871. Este desenvolvimento foi propiciado principalmente em razão da liga aduaneira Zollverein, apesar da oposição austríaca. Segundo Arruda (1980), a Prússia era o estado mais desenvolvido antes da unificação alemã, e, ao tentar controlar as contas reais provocou grande conflito político que só foi apaziguado quando o Rei Guilherme I nomeou Otto Von Bismarck, um político antiliberal e defensor da unificação dos Estados germânicos, como primeiro-ministro. Este passou a governar autoritariamente com o apoio da Câmara dos Nobres, em razão da oposição da burguesia a suas políticas, e, gradativamente, conseguiu a unificação alemã.

De acordo com Beaud (2004), alguns ducados germânicos estavam em poder da Dinamarca, mas, Bismarck, com apoio da Áustria uniu-se aos príncipes destes ducados, notadamente, dois Schleswig e Holstein, e derrotou a Dinamarca. Por outro lado, Napoleão III, durante a guerra entre a Áustria e a Prússia ficou ao lado da Prússia, visando impedir a unificação alemã, uma vez que ela poderia significar a perda da supremacia francesa na Europa. 
Em 1870, portanto, um ano antes de ocorrer a unificação alemã, Bismarck entrou em conflito com Napoleão III, levando a França a entrar em guerra contra a Alemanha. A vitória alemã teve como consequência o desaparecimento do império de Napoleão III e o surgimento da III República Francesa. De acordo com Arruda (1980, p. 213): "O desenrolar dos combates foi fulminante: o exército francês foi vencido [...]. em Paris, os republicanos puseram fim ao império, proclamaram República [...]. Paris foi cercada e três exércitos foram organizados para expulsar os alemães [...]". Os franceses se renderam, perderam Alsácia-Lorena e tiveram que pagar uma indenização de 5 bilhões de francos aos alemães pelo Tratado de Frankfurt. Tiveram que aceitar no palácio de Versalhes o nascimento do Império alemão, em 1871 (SAES; SAES, 2013).

Assim, a partir da do desfecho da guerra entre a França e Alemanha, se iniciou a construção da Alemanha unificada, o seu desenvolvimento e posicionamento no cenário europeu, enquanto, a França, saiu humilhada e tendo que aceitar o Tratado de Frankfurt ${ }^{8}$ (ARRUDA, 1980).

Neste aspecto, as políticas militaristas de Bismarck, sobretudo, no reino prussiano, foram importantes para conseguir a criação do Estado Nacional Alemão, em 1871. Os burgueses não apoiavam as políticas de Bismarck que estendiam o tempo de serviço militar obrigatório e a elevação de impostos para financiar a militarização da Confederação Germânica. Mas, com apoio da Câmara dos Nobres, Bismarck transformou o exército prussiano no principal instrumento de unificação alemã, vencendo em guerra a Dinamarca, a Áustria e a França até criar a Alemanha unificada.

Foi neste contexto, entre 1840 a 1870 que surgiu e se desenvolveu a Escola Histórica Alemã de economia, da qual, para alguns estudiosos, List (1789-1846) não fez parte, enquanto para outros, foi um importante precursor. A seção seguinte abordará em mais detalhes os pressupostos teóricos desta Escola.

\section{ASPECTOS TEÓRICOS-HISTÓRICOS SOBRE A ESCOLA HISTÓRICA ALEMÃ DE ECONOMIA (1840-1870)}

Como foi apresentado na seção anterior denominar a Confederação Germânica de Alemanha é um anacronismo, pois o nascimento deste Estado Nacional só ocorreu em 10 de maio de 1871, depois de uma luta que se estendeu por todo o século XIX. Foi justamente durante este contexto histórico, de luta pela unificação dos estados confederados alemães, que surgiu a Escola Histórica Alemã de economia, a EHA, que, apesar de ser caracterizada pelos estudiosos contemporâneos em três fases, nunca perdeu de vista os pilares fundamentais preconizados pelos seus precursores, do qual se destaca George Friedrich List.

\footnotetext{
${ }^{8}$ Tratado entre a França e a Alemanha assinado na cidade de Frankfurt, em 10 de maio de 1871, prevendo: (i) a cessão dos departamentos franceses que existiam em Alsácia-Lorena e no norte de Lorena à Alemanha; (ii) a permanência do exército alemão em Paris (este permaneceu efetivamente até 1873); e (iii) a cobrança de indenização pela guerra no valor de 5 bilhões de francos a ser paga à Alemanha (BEAUD, 2004). Estas questões seriam novamente reativadas no Tratado de Versalhes, em 1919, após a I Guerra Mundial (1914-1918).
} 
Isto posto, esta seção apresenta os aspectos históricos de surgimento da Escola Histórica Alemã, apontando as principais divergências da referida escola em relação à Escola Clássica de Economia, que representava o modelo e a visão hegemônica da época, além das fases que caracterizam a EHA, destacando os seus pressupostos teóricos mais importantes, objetivando evidenciar que mesmo passando por três fases diferentes, a contraposição desta escola ao pensamento clássico vigente na época decorre de fatores históricos.

\subsection{O SURGIMENTO DA ESCOLA HISTÓRICA ALEMÃ E A SUA CONTRAPOSIÇÃO À ESCOLA CLÁSSICA DE ECONOMIA}

Pode-se dizer que a Escola Histórica Alemã (EHA) surgiu como uma reação à Escola Clássica de Economia (ECE). A ECE, nascida em 1776, com a publicação do livro A riqueza das nações, de Adam Smith, que sofreu influência de duas revoluções. A primeira foi a revolução científica moderna, caracterizada pelo positivismo e racionalismo renascentista, iniciada no século XVI que, segundo Brue (2013), levou as pessoas a não mais aceitarem, sem questionar, as verdades medievais. A segunda foi a I Revolução Industrial, de 1750, ocorrida exclusivamente na Inglaterra, tornando este país a maior potência econômica do mundo, em razão da sua industrialização e da acumulação de capital, oriunda deste processo e das demais atividades econômicas. Como potência hegemônica, a Inglaterra se beneficiou significativamente do livre comércio internacional.

O exemplo inglês tornou os pressupostos teóricos do pensamento econômico clássico, fundamentados no liberalismo econômico, um modelo a ser seguido pelos demais países como caminho universal para o crescimento econômico. Assim, o liberalismo econômico que já vinha sendo preconizado pelos filósofos iluministas e, também pela escola fisiocrática, a partir do crescimento econômico da Inglaterra, ganha amplo espaço. Na base deste pensamento estava a liberdade individual, a ideia de ordem natural, o liberalismo econômico, a defesa da propriedade, dos contratos e da iniciativa privada, com a mínima interferência do Estado/Governo9.

É preciso destacar que, nesta época, ou seja, 1776, na Inglaterra já havia sido instalada a Monarquia Parlamentarista, governada pela burguesia, representada por todos os setores econômicos e não apenas a industrial. A Revolução Gloriosa, de 1688, garantiu este espaço à burguesia inglesa, gerando grandes oportunidades de crescimento a esta classe em todos os setores da sociedade (ARRUDA, 1980).

A Inglaterra se tornou uma nação, ou seja, um Estado Nacional, no século XVI, num processo que vinha se delineando desde o século XIII. Este não foi o caso da Alemanha, que só conseguiu a sua unificação no final do século XIX. Foi justamente esta formação tardia, em relação aos países de

\footnotetext{
${ }^{9}$ O próprio List critica a teoria cosmopolítica de Smith, ressaltando que seus argumentos dissimulavam a verdadeira política inglesa, fortemente protecionista, buscando induzir as demais nações a não utilizarem a mesma política (LIST, 1983).
} 
desenvolvimento capitalista clássico, que explicará a não adequação dos pressupostos teóricos da Teoria Econômica Clássica, ao caso alemão, conforme defenderam os pensadores ligados à Escola Histórica Alemã.

Assim, a EHA de economia, surgida na década de 1840, com publicações de Friedrich List $^{10} \mathrm{e}$ Wilhelm Roscher, tecia severas críticas aos clássicos. Embora a Escola Clássica de Economia fosse um pensamento hegemônico entre os intelectuais da época e governantes, os pensadores alemães entendiam que a "receita" de crescimento ofertado por esta escola só servia para economias com desenvolvimento semelhante ao da Inglaterra. E, definitivamente, este não era o caso da Alemanha, pois a mesma ainda tinha uma árdua luta para a sua transformação em Estado Nacional e, também, possuía uma economia de base totalmente agrícola, excetuando-se as regiões da Prússia e da Áustria.

Então, a EHA surgiu devido à necessidade do desenvolvimento de um modelo de crescimento que mais se adequasse à realidade da Confederação Germânica que possuía uma formação econômica, social e política muito diferente da inglesa. Os pensadores alemães entendiam que as diferenças históricas entre os dois países eram substanciais, para que o modelo inglês fosse adequado à realidade alemã. Essas críticas e objeções à escola de Adam Smith derivaram, tanto da necessidade de um novo modelo de crescimento, quanto da contrariedade com a elevada exploração sofrida pelos trabalhadores no período de desenvolvimento da indústria inglesa.

O início das críticas atinge, segundo Oliveira e Gennari (2009), o âmago da economia política criada e difundida pela obra mais famosa de Smith, baseada na ordem natural e na natureza harmoniosa dos fenômenos e da sociedade. A Escola Histórica Alemã diferenciava os fenômenos da natureza, dos fenômenos relacionados à realidade humana. Isto é, enquanto os clássicos defendiam que a sociedade caminhava automaticamente para o equilíbrio, como a natureza e o corpo humano, sem nenhuma necessidade de comando, os pensadores da Escola Histórica Alemã, entendiam que a sociedade se movimenta de acordo com determinações históricas, geradas pelas ações dos próprios homens.

Assim, de acordo com Oliveira e Gennari (2009), os pensadores alemães acreditavam, diferentemente dos clássicos, que a natureza humana não era imutável fazendo com que surgisse a necessidade de estudos específicos para as ciências humanas, centrados na análise do contexto e das relações históricas e não apenas em modelos matemáticos. Assim, "Numa situação otimista, tal método [o histórico] poderia estabelecer tendências ou regularidades, mas nunca uma lei que descreva o fenômeno com precisão e tenha validade universal" (OLIVEIRA, GENNARI, 2009, p. 190), uma vez que as condições históricas mudam, diferindo do pensamento clássico, com suas leis universais.

\footnotetext{
${ }^{10}$ A mais famosa obra de List foi National system of political economy, publicada em 1841 . Nela List defende a unificação alemã, o nacionalismo e a industrialização promovida pelo Estado. Além de destacar a importância do desenvolvimento de vários estudos, como base no método histórico, para encontrar políticas adequadas à realidade alemã, que, no século XIX não se constituía, ainda, em Estado Nacional. Portanto, no seu entendimento a realidade e o modelo inglês de desenvolvimento não eram adequados à da Confederação Germânica.
} 
Essa diferença entre os fenômenos da natureza e humanos é uma característica básica do historicismo alemão. Como resultado dessa divergência de pensamentos surgiu um embate entre três métodos de abordagem utilizados pelos clássicos: o Indutivo, o Dedutivo e o Abstrato ${ }^{11}$. Destes três métodos, os historicistas adotaram apenas foi o método indutivo já que nesta abordagem a história é utilizada para explicar os fenômenos sociais do passado e contemporâneos. Quanto aos métodos de procedimentos, utilizaram o histórico e o estruturalismo, atacando o universalismo dos teoremas econômicos. "Isso porque a economia é dependente dos fenômenos históricos específicos de cada povo e, portanto, deve se dedicar a um estudo rigoroso da realidade histórica e não à dedução de teoremas de acordo com a lógica" (MAXIMO, 2010, p. 4).

Quanto ao autointeresse ou psicologia individual defendida pelos clássicos, sobretudo por Smith, quando aborda a tomada de decisões do indivíduo, sugerindo que este é movido pelo autointeresse e apontando, esse comportamento como fonte geradora de benefícios coletivos, os pensadores alemães acreditavam que não era uma ideia válida universalmente como defendiam os clássicos, uma vez que as motivações humanas são complexas afetadas pela moralidade, leis e costumes, e não somente pelo autointeresse. Além disso, a EHA também criticava à ideia de que a sociedade seria: "a soma de um conjunto de indivíduos atuando mecanicamente em busca do próprio interesse" (OLIVEIRA, GENNARI, 2009, p. 191). Para a Escola Histórica Alemã, a sociedade não pode ser entendida como a ação do indivíduo, mas, sim, em suas diversas e complexas interações coletivas.

Os alemães tinham a consciência que a unificação tardia da Alemanha em relação à inglesa, dois séculos depois, acarretaram vantagens na acumulação de capital que contribuíram para facilitar o processo de industrialização da Inglaterra ainda em meados do século XVIII. A Alemanha que só se unificou no final do século XIX, possuía algumas indústrias, mas não um processo de industrialização avançado. Portanto, para estes pensadores, era necessário, por parte da Alemanha, a adoção de políticas econômicas e governamentais diferentes das inglesas (BEAUD, 2004).

Para Brue (2013) a Escola Histórica Alemã possui quatro princípios primordiais. São eles: (i) abordagem desenvolvimentista para a economia tendo como base a industrialização a ser promovida e protegida pelo Estado; (ii) ênfase no papel intervencionista do Estado protegendo, em especial, a indústria nascente e promovendo a construção de ferrovias; (iii) abordagem indutiva e histórica como método de análise da economia e da sociedade; e (iv) defesa de uma reforma administrativa conservadora.

No que se refere à abordagem desenvolvimentista para a economia, os pensadores alemães compararam o evolucionismo de Darwin, com a sociedade - afirmando que um organismo social nasce, desenvolve-se, cresce, enfraquece e morre - visando evidenciar as constantes mudanças sociais e,

\footnotetext{
${ }^{11} \mathrm{O}$ método indutivo, parte de premissas particulares para gerais no estudo dos fenômenos. O método dedutivo parte de premissas gerais para o particular no estudo dos fenômenos. O método abstrato trabalha com modelos e situações abstratas, para explicação de objetos concretos.
} 
portanto, como ela não é estática, uma doutrina econômica relevante para determinado país pode ser inadequada para outro (BRUE, 2013). Com isso destacavam a impossibilidade do desenvolvimento de leis naturais universalmente válidas, como teorizavam os clássicos.

Em relação à ênfase no papel positivo do governo, relaciona-se à importância credita pela escola ao problema do desenvolvimento econômico. Esta enfatizava o papel do Estado e da sociedade como os principais indutores do desenvolvimento econômico e social. Os pensadores alemães, diferente dos clássicos que defendiam uma menor interferência do Estado na economia, acreditavam que para atingir esse desenvolvimento seria necessária a intervenção do Estado em assuntos econômicos (BRUE, 2013).

Quanto aos métodos de análise da sociedade, utilizavam a indução, o estruturalismo e o método histórico, sempre enfatizando a importância de se estudar historicamente a economia e de combinar este estudo com outros ramos da ciência social, diferindo do método clássico abstrato e dedutivo (BRUE, 2013).

Com a defesa da reforma conservadora os economistas alemães buscavam afastar as ideias socialistas da classe trabalhadora, uma vez que as reformas acarretariam na melhoria das condições de vida e bem-estar social (BRUE, 2013).

É, evidente, que a importância destes pilares variou em virtude do momento histórico em que os pensadores se encontravam, inclusive com adição de novos pressupostos. Em razão destas variações a Escola Histórica Alemã de Economia (EHA) passou por, pelo menos, duas fases, as quais são tratadas na subseção seguinte, além de uma terceira chamada de Novíssima Escola Histórica, que não aderiu ao pensamento listiano.

\subsection{CARACTERIZAÇÃO DAS FASES DA ESCOLA HISTÓRICA ALEMÃ E SEUS PRINCIPAIS PRESSUPOSTOS TEÓRICOS}

A Escola Histórica Alemã de economia pode ser dividida em duas fases: a Antiga Escola Histórica Alemã (AEHA) e a Nova Escola Histórica Alemã (NEHA). A Antiga Escola surgiu no período de 1840 e terminou em 1860, sendo representada por Wilhelm Roscher (1817-1894), Bruno Hildebrand (1812-1878) e Karl Knies (1821-1917). A Nova Escola, originada em 1860 foi liderada por Gustav Schmoller (1838-1917). Para alguns historiadores, ainda, existe a Novíssima Escola Histórica Alemã que é representada por Arthur Spiethoff (1873-1957), Werner Sombart (1863-1941) e por Max Weber (1864-1920). No presente estudo, trabalha-se com as duas primeiras tendo List como seu precursor, por defenderem, claramente, as ideias que também eram defendidas por List, em 1841.

\subsubsection{A Antiga Escola Histórica Alemã (AEHA)}

O objetivo da Antiga Escola Histórica Alemã (AEHA) foi buscar dados históricos e econômicos para a criação, de modo científico e intuitivo, de políticas sociais e econômicas. Os seus três representantes Roscher, Hildebrand e Knies, caracterizam, segundo Mekaru (2016, p. 16), “o desenvolvimento econômico como uma 
sucessão de etapas, ainda que diferissem entre si nos detalhes, o que indica uma herança do meio intelectual alemão da época".

Para alguns pesquisadores, Wilhelm Roscher é considerado o fundador da AEHA. Sua principal obra é Grundiss zu Vorlesunger über die Staatswirtschaft nach Geschichtlicher Methode, publicada em 1843. Apesar de ser o primeiro representante de AEHA, Roscher não foi um crítico severo da teoria clássica. Ele, inclusive, não chegou a descartar o método dedutivo utilizado pelos clássicos na análise econômica, destacando a necessidade da utilização conjunta deste com observações empíricas (OLIVEIRA; GENNARI, 2009).

O primeiro representante da escola a criticar abertamente a Escola Clássica de Economia foi Hildebrand. De acordo com Oliveira e Gennari (2009, p. 196), Hildebrand "Considerava que o objeto de estudo dos economistas era a evolução da experiência econômica da humanidade, que essa tarefa consistia num exame detalhado do desenvolvimento de cada povo, em particular, e da humanidade, em geral". Além disso, enfatizava a importância da integração da histórica econômica com outras disciplinas, para o sucesso desse estudo. Sua principal obra é Die Nationalökonomie der Gegenwart und Zukunft, publicada em 1848.

O mais prestigiado integrante da AEHA, Karl Knies, foi quem apresentou e colocou em prática a metodologia mais precisa desta escola de pensamento. Para Knies a economia só pode ser abordada do ponto de vista de estudos históricos, já que a história é determinante para doutrinas e políticas. "Apesar da impossibilidade de se estabelecerem leis universais, os estudos históricos podem indicar regularidades e sugerir analogias na evolução social das comunidades ou nações e, consequentemente, orientar a ação dos governos e do Estado" (OLIVEIRA; GENNARI, 2009, p. 197). Sua principal obra é Die Politische Oekonomie vom Standpunkte der Geschichtlichen Methode, de 1853.

De acordo com Goularti Filho (1999), para Knies é de fundamental importância o entendimento de que as instituições econômicas e sociais, bem como as transformações ocorridas no período estudado, o espaço geográfico e os povos, pois geram mudanças nas relações de trabalho e nas funções do Estado/Governo. Logo, a visão dos economistas clássicos de universalização do seu pensamento, dos seus modelos e das leis naturais não funciona para todas as economias e sociedade, de forma hegemônica.

Para o autor, os fundamentos da Escola Histórica Alemã são, exatamente, iguais aos defendidos por George Friedrich List, em 1841. Assim, apesar de alguns pesquisadores não classificarem List como membro da Escola Histórica Alemã, Goularti Filho (1999) defende que a melhor classificação para List seria como fundador da referida escola, sendo a visão adotada por este trabalho.

\subsubsection{A Nova Escola Histórica Alemã (NEHA)}

Para Mekaru (2016), foi na NEHA que a Escola Histórica Alemã atingiu seu ponto alto em tamanho e influência. Suas características mais importantes são: (i) destaque à dimensão moral da economia, que monitoria os interesses privados para haver um controle, caso necessário; (ii) elo entre indivíduo e sociedade; (iii) o Estado como condutor dos objetivos da sociedade; e, (iv) não limitar o 
papel do economista apenas à área acadêmica, estendendo suas influências para a esfera pública. Da AEHA foi mantida, também, a ideia de que não há uma lei universal para a teoria econômica.

Devido à conjuntura vivida pela Alemanha no final do século XIX, os economistas da NEHA foram capazes de aplicar suas reformas com maior facilidade. Em relação a metodologia utilizada pelos economistas alemães, a rejeição do método dedutivo deriva da compreensão que estes tinham da economia e das motivações humanas, ambas complexas e com múltiplas causas, demandando necessariamente um estudo histórico profundo, muito além da generalização dedutiva dos clássicos (MEKARU, 2016).

O maior representante dessa escola é Gustav Schmoller, reconhecido por apoiar pesquisas históricas no campo da economia e, como os outros economistas da EHA, era contra a ideia da universalidade das teorias econômicas. Dedicou boa parte de sua vida profissional a realizar e orientar trabalhos monográficos que abordavam a história econômica germânica. Schmoller creditava importância a produção monográfica pois, segundo Oliveira e Gennari (2009, p. 197), "Defendia que a produção das monografias era uma pré-condição para a compreensão do contexto geral, este, sim o objetivo final dos estudos econômicos".

Foi Schmoller o responsável por um dos eventos mais notórios desta Escola, o Methodenstreit, ou Batalha dos Métodos, uma conhecida controvérsia travada entre Schmoller e Carl Menger, fundador da Escola Marginalista da Áustria, sobre os métodos dedutivo e indutivo, em 1883. O que se questionava era qual destes dois métodos seriam mais produtivos para a Ciência Econômica (BRUE, 2013).

Menger, em sua obra Untersuchungen Über die Methode der Sozial Wissenschaften und der Politischen Oekonomie Insbesondere, publicada em 1883, atacou diretamente as convicções da EHA sobre a superioridade do método histórico sobre o dedutivo, pautado em princípios e leis universais (OLIVEIRA; GENNARI, 2009).

O uso do método histórico estava no auge do sucesso e Menger publicou um livro sobre metodologia e classificou a Escola Histórica de Schmoller como sem importância, secundaria, irrelevante. Schmoller publicou uma crítica veemente ao livro de Menger (BRUE, 2013).

Menger retrucou com Schmoller através da publicação de um panfleto. Quando Schmoller recebeu o panfleto escrito por Menger, publicou uma nota afirmando que não iria criticar Menger, pois havia devolvido o panfleto a ele, só que no envelope de devolução adicionou uma cópia da sua nota crítica que fora publicada. Foram muitos ressentimentos e várias publicações de insultos entre os dois.

No seu livro Political economy and method, publicado em 1894, Schmoller reafirmou a importância do método histórico para a ciência econômica. No âmbito social, defendeu a importância dos valores éticos e da justiça no sistema econômico. Reformas que no seu entendimento deveriam ser promovidas pelo Estado e pela sociedade. A base desta reforma deveria ser a distribuição justa de renda, por meio de políticas sociais (BRUE, 2013). 
A polêmica guerra dos métodos, estendeu os debates metodológicos por quatro décadas, sem que nenhum dos lados fosse considerado vitorioso. Contudo, "a discussão deixou a certeza entre os estudiosos de que qualquer abordagem consistente não poderia prescindir de uma estrutura teórica coerente nem de uma pesquisa histórico-concreta cuidadosa" (OLIVEIRA; GENNARI, 2009, p. 198).

Schmoller, entedia que o estudo histórico da Antiga Escola Histórica Alemã não foi suficiente para oferecer uma base empírica para a teoria econômica da Alemanha, portanto, era preciso a ampliação e aprofundamentos dos estudos históricos para fundamentar a teoria econômica alemã. Em relação à industrialização e ao protecionismo, apresentou ideias diferentes durante sua vida, defendendo o liberalismo, na juventude, e o protecionismo, na velhice, período no qual aprovou tarifas protecionistas, como importantes mecanismos para o desenvolvimento da indústria nacional, e proclamou List, um de seus mestres (BRUE, 2013).

\subsubsection{A Novíssima Escola Histórica Alemã}

Diferente da EHA, os economistas pertencentes à Novíssima EHA deixaram de abordar o método dedutivo e a teoria dos problemas econômicos de uma forma hostil. Passaram a adotar abordagens que unissem métodos empíricos e teóricos, destacando: a importância de estudos abrangentes, envolvendo as particularidades históricas e elaboração de generalizações a partir destas; bem como a necessidade de observação da relação entre a vida econômica e a estrutura social para o melhor entendimento dos fenômenos econômicos, creditando significativa importância à cultura, moral e religião na tomada de decisão dos agentes econômicos, ultrapassando "em larga escala o ponto de vista utilitarista e neoclássico que, por sua vez, associava a ação racional dos agentes econômicos ao princípio da busca do lucro e do prazer" (OLIVEIRA; GENNARI, 2009, p. 198-199).

Os autores mais célebres desta escola foram: Arthur Spiethoff, Werner Sombart e Max Weber ${ }^{12}$. Arthur Spiethoff (1873-1957), foi assistente de Schmoller sendo considerado seu herdeiro intelectual. Tendo como principais contribuições as relacionadas com o entendimento dos ciclos econômicos, e o conceito de estilos econômicos (MEKARU, 2016).

Max Weber (1864-1920) foi professor de Economia Política na Alemanha e se considerava um pensador descendente de Schmoller. Publicou em 1904, A ética protestante e o espírito do capitalismo, no qual levantou grande controvérsia ao discutir, entre outras coisas, a relação entre capitalismo e protestantismo.

Werner Sombart (1863-1941) foi um historiador econômico que se contrapôs as ideias de Max Weber a respeito do protestantismo, ao argumentar que a formação de natureza capitalista dos empresários se devia à religião judaica e não a protestante. Sombart era nacionalista, como os pensadores

\footnotetext{
${ }^{12}$ Weber e Sombart não eram economistas e, para algumas correntes teóricas, não fazem parte da EHA, mas foram autores importantes para o desenvolvimento da Sociologia Econômica que é considerada um novo ramo das ciências sociais aplicadas.
} 
alemães da Escola Histórica, contudo, em 1933, passou a defender as ideias nazistas e o governo Hitler, exaltando o racismo e o nacionalismo como alternativas à Alemanha derrotada na I Guerra Mundial (1914-1918) (BRUE, 2013).

\section{FRIEDRICH LIST E O SISTEMA NACIONAL DE ECONOMIA POLÍTICA}

Nesta seção apresentam-se as principais ideias preconizadas por List, para o desenvolvimento dos estados que compunham a Confederação Germânica, com vistas à sua unificação e a formação do Estado Nacional Alemão, a Alemanha.

O objetivo é mostrar que, embora List tenha falecido em 1846 e a Alemanha só ter conseguido se tornar um país em 1871, os estudos teóricos de List, na sua obra "Sistema Nacional de Economia Política”, publicada em 1841, contribuíram para o surgimento da Escola Histórica Alemã ${ }^{13}$, nas suas duas primeiras fases, de 1840 a 1870, já que a terceira - A Novíssima Escola Histórica Alemã seguiu outros caminhos.

As principais contribuições deste precursor à EHA foram: o uso do método histórico na Ciência Econômica, a defesa do Estado na promoção da industrialização e na proteção da indústria nacional nascente, a defesa da unificação alemã e a criação de infraestrutura, como a construção de ferrovias.

\subsection{FRIEDRICH LIST, PRECURSOR E FUNDADOR DA ESCOLA HISTÓRICA ALEMÃ DE ECONOMIA}

List nasceu em Württemberg, em 1789, no ano da Revolução, em uma Alemanha fragmentada em mais de 200 estados, denominada Império Sacro-Germânico. Somente em 1818, todo o território que viria formar a Alemanha em 1871, tornou-se a chamada Confederação Germânica. Levando à unificação de alguns estados, reduzidos a 39. Apesar da sua defesa pela unificação alemã em um Estado Nacional, List não viveu para ver este sonho ser concretizado, pois faleceu em 1846 (GOULARTI FILHO, 1999).

Excetuando-se as regiões da Áustria e da Prússia, a maioria dos estados da Confederação Germânica eram de base agrícola, o modelo econômico era baseado no modelo mercantilista com moedas próprias, um mercado nacional, uma indústria subdesenvolvida, se comparada ao desenvolvimento inglês e francês, e uma burocracia que impedia ainda mais o desenvolvimento. Com a abertura dos rios Reno e Danúbio ao comércio internacional, aprovada pelo Congresso de Viena, a Inglaterra intensificou seu domínio sobre o comércio dos estados da Confederação Germânica (ARRUDA, 1980).

Na área econômica, o domínio comercial inglês fez com que um dos estados mais poderosos da Confederação, como a Prússia, planejasse elevar a integração comercial entre os Estados Germânicos, através de isenção de impostos sobre produtos manufaturados, diminuição de tarifas, criação da

\footnotetext{
${ }^{13}$ Em consonância com autores como: Brue (2013), Goularti Filho (1999) e Oliveira e Gennari (2016).
} 
Associação Comercial Manufatureira Alemã, para facilitação do livre comércio entre os membros, e proteção das manufaturas de concorrência estrangeira. Essa diminuição de barreiras ao comércio ocorreu até 1834 quando o Zollverein foi formalizado.

$\mathrm{Na}$ esfera cultural e ideológica o domínio inglês deu origem a três tipos de reação: (i) a burguesia, nutria simpatia pelas ideias de Smith e Ricardo com ideias liberais na economia e política; (ii) a nobreza temia essas ideias, reagindo através de manifestações que visavam destacar que as ideias liberais não se adequavam ao momento passado pelos Estados Germânicos; (iii) os intelectuais reagiram defendendo a ideia de que somente um Estado forte e intervencionista proporcionaria o desenvolvimento industrial da região.

Oliveira e Gennari (2016) destacam que Friedrich List foi o primeiro a apresentar uma análise que enfatizava o papel do Estado no desenvolvimento da indústria nacional, o que lhe garante a originalidade do pensamento e o papel de precursor desta teoria e de fundador da Escola Histórica Alemã, que manteve seus principais pressupostos teóricos por cerca de três décadas. Ademais, o pensamento Listiano serviu de base para a elaboração do pensamento cepalino na América Latina e no Brasil, entre os anos 1940 a 1960.

List foi além de teórico, foi militante ativo de suas ideias, preocupado com o seu país e com a população mais pobre. Após sua demissão, de um cargo administrativo da Universidade de Tübingen, em 1819, List passou a militar por uma união política e comercial entre os Estados alemães, tornandose deputado de seu Estado, em 1820, advogando em defesa de reformas consideradas radicais.

Ele concedeu benefícios abolindo pedágios nas estradas, dízimos, propriedade estatal das industrias, impostos das propriedades feudais e limitações sobre uso produtivo da terra e impostos sobre consumo. Defendeu o julgamento por júri, a redução no número de funcionários públicos civis e um único imposto direto para cobrir despesas do governo (BRUE, 2013, p. 200).

Devido à radicalidade de suas ideias, List, de intensa defesa à indústria e modernização administrativa em menos de um mês sua casa foi invadida, seus panfletos foram destruídos foi acusado de sedição, condenado a 10 meses de prisão. Ele recorreu ao rei do exílio, mas ao voltar para a Alemanha foi preso. Com o fim da pena, foi expulso do país, partindo para os Estados Unidos onde viveu de 1825 a 1832 tralhando como fazendeiro, jornalista e promotor de vendas, ganhando e perdendo fortunas em minas de carvão. Foi no exílio que as ideias de List ganharam fama, inclusive, nos Estados Unidos (LIST, 1983 e BRUE, 2013).

Em seu retorno para a Confederação Alemã, List ressaltou a importância da construção de uma rede ferroviária, que seria implantada posteriormente, evidenciando a razão de List quanto a defesa desta. Após anos de problemas de saúde e pessoais, List cometeu suicídio em 1846. 


\subsection{O SISTEMA NACIONAL DE LIST E O MODELO DE CRESCIMENTO PROPOSTO PARA A CONFEDERAÇÃO GERMÂNICA NO SÉCULO XIX}

A principal obra de List, "O Sistema Nacional de Economia Política”, é iniciada com uma crítica ao universalismo da economia inglesa, a quem chamou de Economia Cosmopolítica. Segundo List, antes de François Quesnay publicar seu "Tableau Économique”, em 1759, a análise econômica se restringia a atividades exercidas por servidores e administradores públicos, que nos estudos econômicos, preocupavam-se, exclusivamente, com "a agricultura, as manufaturas, o comércio e a navegação dos países aos quais pertenciam, sem analisar as causas da riqueza ou levar em consideração os interesses de toda a humanidade" (LIST, 1983, p. 89).

De acordo com List (1983), Quesnay em sua investigação, se contrapôs à visão de Economia Cosmopolítica, propondo uma Economia Política Nacional. No centro das atenções de Quesnay estava a preocupação com a prosperidade de uma nação, a francesa, por meio do comércio e da agricultura.

Para List, Smith, assim como Quesnay, acreditava na liberdade total de comércio entre toda a humanidade, porém, em “A Riqueza das Nações”, publicada em 1776, Smith tenta desqualificar a verdadeira Economia Política, para que seja substituída pela Economia Cosmopolítica ou mundial. List opõe-se, veementemente, a esta visão de Smith porque, para List, as formações históricas de cada nação e suas realidades devem ser analisadas nas suas individualidades/particularidades. List também discorda de Smith no que se refere à chamada paz perpétua. De acordo com List (1983, p. 89-90):

\footnotetext{
A ideia de um perpétuo estado de paz constitui o fundamento de todos os seus argumentos. Além disso, [...] desde o início suas investigações se baseiam no princípio de que "a maior parte das regulamentações dos Estados para a promoção da prosperidade pública são desnecessárias, e uma nação, para passar do estado da mais baixa barbárie para o estado da mais alta prosperidade possível, não necessita de outra coisa senão de taxas suportáveis, administração honesta da justiça e da paz".
}

O economista Jean Baptiste Say, muito conhecido em razão da "Lei dos Mercados" conhecida, ainda, como "Lei de Say" também teve suas ideias amplamente criticadas por List, o que o autor denominou de Economia Política claramente cosmopolítica. Para List, ao fazer isso, Say abriu mão de qualquer explicação sobre como seria a raça humana dividida em inúmeras nações, culturas e religiões diferentes. O que é um ato imperdoável, já desconsidera os determinantes históricos de cada nação nas relações humanas.

List (1983) acreditava que o nacionalismo, fundamentado na liberdade civil, no trabalho, nos nexos morais e éticos, nos recursos naturais, no potencial da agricultura e, principalmente na indústria, é elemento aglutinador do povo. A defesa do protecionismo age como estímulo à indústria nacional e anima os empresários e operários na busca de melhor qualificação e tecnologia. Também beneficia o capital estrangeiro que se sente compensado pelos subsídios à produção. Essa nova teoria protecionista, iniciada por List no início do século XIX, tem como objetivo confrontar a teoria clássica de Smith e 
fornecer meios para superar o atraso alemão e norte-americano em relação à Inglaterra, maior potência da época.

A Escola Clássica, segundo List (1983), cometeu o erro de considerar o futuro desejado por eles, como a paz perpétua e a união universal das nações para atingir o livre comércio, como certo. Para List, a paz perpétua só existe nas nações que já estão unidas politicamente e comercialmente. Historicamente esta é a única forma de ocorrer as uniões, políticas e comerciais. A liberdade comercial, nas condições vividas pelo mundo do século XIX, não seria universal já que os países menos desenvolvidos sempre estariam na desvantagem.

Para que a liberdade aconteça, de acordo com List (1983), de forma mais igualitária seria necessário que as nações atingissem o mesmo nível de desenvolvimento industrial, civilizatório, cultural, político e de poder. Em razão da existência de desigualdade entre as nações, que o livre comércio não seria a melhor política para todos os países. Apenas com um sistema protecionista seria possível reduzir tais diferenças, nivelando o desenvolvimento de todas as nações e possibilitando a união com outras nações desenvolvidas para a prática do livre comércio.

Para List (1983, p. 3-4), foi um grande erro dos autores da economia política clássica, não levar em consideração as características individuais de cada nação:

Percebi claramente que a livre concorrência entre duas nações altamente civilizadas só pode ser mutuamente benéfica no caso de ambas estarem em um grau de desenvolvimento industrial mais ou menos igual; ao contrário, qualquer nação que, em razão de reveses, estiver atrasada em relação a outra, do pondo de vista industrial, comercial ou naval, embora possua os meios mentais e materiais para desenvolver-se, deve antes de tudo aumentar e consolidar seus próprios poderes individuais para aparelhar-se a entrar na livre concorrência com nações mais evoluídas. Em uma palavra, dei-me conta da distinção entre a Economia Cosmopolítica e a Economia Política. Percebi que a Alemanha deve abolir suas tarifas alfandegárias internas e, adotando uma política comercial uniforme e comum em relação aos estrangeiros, procurar atingir o mesmo grau de desenvolvimento comercial e industrial, alcançado por outras nações mediante sua política comercial.

List (1983) apresenta o sistema protecionista como a solução para o desenvolvimento econômico, mas considera-o apenas como um estágio, uma vez que a partir do desenvolvimento é importante a adoção do livre comércio. Esse estágio ocorre, pois, o sistema nacional se modifica de acordo com os estágios de progresso de um país (GOULARTI FILHO, 1999).

São três os estágios: no primeiro, o país adota o livre comércio com nações mais desenvolvidas como mecanismo de sair do estado de barbárie e para progredir na agricultura; no segundo estágio, adota o protecionismo para promover o crescimento das indústrias, da pesca, da navegação e do comércio exterior; após atingir elevado grau de desenvolvimento econômico, passa para o último estágio, que é o livre comércio e a concorrência sem restrições, afastando a indolência e a acomodação dos capitalistas nacionais (GOULARTI FILHO, 1999, p. 111-112).

List (1983), desenvolveu essa teoria com base no estudo da história de 10 nações: Itália, Suíça, Holanda, Inglaterra, Espanha, Portugal, França, Alemanha, Rússia e os Estados Unidos. Observou que o progresso da indústria nacional protegida, nesses países, gerou crescimento econômico. A observação 
empírica destas nações evidenciou que nos períodos em que vigoravam medidas protecionistas houve crescimento econômico, já com o livre comércio, as nações apresentaram decadência. Além disso, concluiu, com base em seus estudos, que o crescimento um Estado centralizador e forte com objetivos industrializantes e neutralizador dos interesses antagônicos à indústria. Sem a intervenção de um Estado forte há falta de segurança, dos cidadãos e de instituições chaves de uma nação, e de confiança na moeda do país. Assim,

O Governo, [...], não só tem o direito, mas é seu dever promover todas as coisas que podem aumentar a riqueza e o poder da nação, se este objeto não pode ser efetuado pelos indivíduos. Por isso, é seu dever proteger o comércio com uma Marinha, porque os comerciantes não podem se proteger; por isso, é seu dever proteger o negócio do comércio por leis de navegação, [...], a agricultura e todas as outras indústrias por meio de estradas, pontes, canais, ferrovias, e as novas invenções por meio de leis de patentes, de modo que as fábricas devem ser erguidas por direitos de proteção, se o capital estrangeiro e a habilidade de impedir o indivíduo de realiza-los (LIST, 1909, p. 148 apud OLIVEIRA, 2017, p. 7).

Segundo List (1983) o quarto fator de crescimento, e talvez o mais importante, em questão de dedicação, são as ferrovias, condição necessária para a formação da nação e crescimento econômico já que estimulariam o desenvolvimento industrial, porque exigiriam novos produtos, promoveriam a inovação, barateariam o transporte e o tornariam mais rápido, além aumentar a mobilidade da mão de obra e ampliar mercados. List chegou a projetar traçados de ferrovias, de tão essencial que considerava ser este meio de transporte, por possibilitarem a integração e, por isso, o autor foi um defensor da construção de um sistema de linha férrea que interligasse todo o território alemão, Europa e Ásia.

List percebeu a importância das ferrovias, como mecanismo de unificação do mercado nacional e das forças produtivas, no período em que viveu nos Estados Unidos. Sobre este período List (1983, p. 5) escreveu: "Quando, depois disso, visitei os Estados Unidos, pus de lado todos os livros - pois a essa altura só tenderiam a desencaminhar-me da via certa. A melhor obra sobre Economia Política que se possa ler naquele país moderno é a vida real". List faleceu antes de suas ideias serem aplicadas, mas grande parte das ferrovias alemãs construídas posteriormente seguiram os traçados propostos em seus projetos.

\section{CONSIDERAÇÕES FINAIS}

Após décadas de conflitos políticos, territoriais e econômicos a tão sonhada unificação, dos Estados que formavam a Confederação Germânica, ocorreu, dando origem à Alemanha, em 1871. Não foi apenas uma unificação geográfica, foi também uma unificação política e econômica que possibilitou à Alemanha ser a potência que é hoje.

A história da Alemanha se diferencia muito em relação aos seus vizinhos já que o processo de desenvolvimento alemão é considerado um desenvolvimento tardio, pois, enquanto seu território estava dividido em dezenas de territórios e sua indústria era subdesenvolvida, os outros países, que se tornaram 
estados nacionais no século XVI, já estavam bem desenvolvidos, inclusive, industrialmente, a exemplo da Inglaterra, país onde ocorreu a I Revolução Industrial, em 1750.

Existiam potências mundiais como Inglaterra, França e, uma ex-colônia inglesa, os Estados Unidos. A Escola Histórica Alemã, surgida no século XIX, foi fundamental para a criação de soluções para o desenvolvimento e, também, para se contrapor à escola de pensamento econômico que dominava o mundo naquela época, a Escola Clássica de Economia. O Zollverein, que sofreu influências dos historicistas alemães, é considerado por muitos como um grande responsável pelo processo que levou à unificação nacional alemã, em 1871.

Neste artigo abordou-se o contexto de surgimento da Escola Histórica Alemã, um dos alicerces para a formação do Estado Nacional e desenvolvimento da indústria, e de seu maior representante, Friedrich List, que participou diretamente do surgimento do Zollverein e das propostas para o crescimento econômico alemão, por meio da intervenção estatal, a promoção da proteção da indústria nascente e a criação das estradas de ferro, mesmo essas tendo surgido após sua morte ocorrida em 1846.

Devido ao subdesenvolvimento da maioria dos Estados da Confederação Germânica era bem clara a ineficácia do modelo clássico de economia para aquela realidade. E List apontou esta inadequação do pensamento econômico clássico para economias de capitalismo tardio como o da "Alemanha". Para o autor, era pretensão da Escola Clássica querer ser universalista e cosmopolítica porque cada nação tem suas realidades próprias e, portanto, precisam encontrar, com base na disponibilidade de seus recursos, seus caminhos para o desenvolvimento. Neste aspecto, sobretudo, List era bem nacionalista, além disso ressaltou que o modelo proposto pelos economistas clássicos só era vantajoso para nações que já possuíam uma indústria desenvolvida, o que não era o caso da Alemanha. Foi neste cenário que List realizou diversas críticas aos clássicos, especialmente a Adam Smith e suas ideias de nação e comércio.

O pensamento de Friedrich List, para o desenvolvimento alemão, estava correto. Somente através do protecionismo, nacionalismo e um Estado centralizador que a Alemanha se desenvolveria. Em 1913, a Alemanha já era uma das nações mais industrializadas do mundo, sendo acusada de ser o estopim da I Guerra Mundial (1914-1918). Hoje, mais de um século depois, as ideias de List continuam atuais em razão da existência diferenças entre os níveis de desenvolvimento das nações e a propagação da teoria que ressalta a importância do livre comércio, como caminho para o desenvolvimento. Como o estudo do caminho do desenvolvimento de diversas nações, inclusive a alemã, apontam, o livre comércio não deve ser adotado como política de desenvolvimento, mas em uma etapa posterior. Contudo, um Estado forte e impulsionador do crescimento do setor industrial, são condições indispensáveis para a superação do subdesenvolvimento. 


\section{REFERÊNCIAS}

ARRUDA, J. J. História Moderna e Contemporânea. 12 ed. São Paulo: Ática, 1980.

BEAUD, M. História do capitalismo: de 1500 aos dias atuais. São Paulo: Brasiliense, 1996.

BRUE, S. A Escola Histórica Alemã. In: BRUE, S. História do pensamento econômico. 4 reimp. São Paulo: Cengage Learning, 2013, p. 195-211.

FREITAS, E. P. Viriato Soromenho-Marques. Portugal na queda da Europa. Revista Brasileira de Ciência Política, Brasília, n. 17, p. 277-286, maio/ago. 2015. Disponível em:

http://www.scielo.br/pdf/rbcpol/n17/0103-3352-rbcpol-17-00277.pdf. Acesso em: 12 maio 2019.

GOULARTI FILHO, A. List e o Sistema Nacional de Economia Política. Leituras de Economia

Política, Campinas, v. 7, p. 105-114, 1999.

HUBERMAN, L. História da Riqueza do Homem. 22. ed. São Paulo: Saraiva, 2011.

LIST, G. F. Sistema Nacional de Economia Política. São Paulo: Abril Cultural, 1983.

MAXIMO, M. M. A. A Guerra dos Métodos: a visão da Escola Histórica Alemã. In: ANAIS [...] ENCONTRO REGIONAL DA ASSOCIAÇÃO NACIONAL DE HISTÓRIA (ANPUH-RIO), 14, 2010, Rio de Janeiro, ANPUH-RIO, 2010.

MEKARU, M. Y. A Escola Histórica Alemã e suas questões historiográficas. Campinas, 2016. 57f. Trabalho de conclusão de curso (Bacharel em Ciências Econômicas) Instituto de Economia. Universidade Estadual de Campinas, Campinas, 2016.

OLIVEIRA, F. S. Bases do Nacionalismo Econômico em Friedrich List. Vitória, 2017. 295f. Tese (Doutorado em História) Programa de Pós-Graduação em História do Centro de Ciências Humanas e Naturais. Universidade Federal do Espírito Santo, Vitória, 2017.

OLIVEIRA, R; GENNARI, A. M. A Escola Histórica. In: OLIVEIRA, R; GENNARI, A. M. História do pensamento econômico. São Paulo: Saraiva, 2009, p. 189-212.

SILVA, T. F. Unificação da Alemanha. Disponível em:

https://www.infoescola.com/historia/unificacao-da-alemanha/. Acesso em: 05 dez. 2017.

SAES, F. A. M de; SAES, A. M. História Econômica Geral. São Paulo: Saraiva, 2013.

SHEEHAN, J. J. German History: 1780-1866. Oxford: Oxford University Press, 1989.

TREUE, W. Alemania desde 1848: ojeada histórica. Bad Godesberg: Inter Nationes, 1969.

VIEIRA, M. C. A formação do estado e do mercado nacionais alemães: uma perspectiva histórica. Rio de Janeiro, 2006. 159f. Tese (Doutorado em Economia Industrial) Programa de Pós-Graduação em Economia Industrial. Instituto de Economia. Universidade Federal do Rio de Janeiro, Rio de Janeiro, 2006. 